\title{
The Correlation of Bone Mineral Density (BMD), Body Mass Index (BMI) and Osteocalcin in Postmenopausal Women
}

\author{
Nike Hendrijantini ${ }^{1 *}$, Rostiny Alie ${ }^{1}$, Rosy Setiawati ${ }^{2}$, Eha Renwi Astuti ${ }^{3}$ and Manggala Pasca Wardhana ${ }^{4}$ \\ ${ }^{1}$ Department of Prosthodontics, Faculty of Dental Medicine, Airlangga University, Indonesia \\ ${ }^{2}$ Department of Radiology, Faculty of Medicine, Airlangga University, Indonesia \\ ${ }^{3}$ Department of Radiology, Faculty of Dental Medicine, Airlangga University, Indonesia \\ ${ }^{4}$ Department of Obstetrics and Gynecology, Faculty of Medicine, Airlangga University, Indonesia
}

*Corresponding author: Nike Hendrijantini, Department of Prosthodontics, Faculty of Dentistry, Airlangga University, Surabaya, Indonesia, Tel: 62-81-134-1610; E-mail: hendrijantininike@yahoo.com

Received date: June 15, 2016; Accepted date: July 25, 2016; Published date: August 01, 2016

Copyright: (c) 2016 Hendrijantini N, et al. This is an open-access article distributed under the terms of the Creative Commons Attribution License, which permits unrestricted use, distribution and reproduction in any medium, provided the original author and source are credited.

\begin{abstract}
Background: Osteoporosis is related to the decrease of bone density, osteoporosis requires attention from dentists because it can also occurs in the jaw bone. Osteoporosis is calculated with a quantitative assessment of bone density, which is called Bone Mineral Density (BMD). The best imaging modalities to assess bone density are the Dual Energy examination methods X-ray Absorptiometry (DEXA). In addition to DEXA, osteoporosis examination can be performed with measurement of Body Mass Index (BMI), which is a ratio of weight and height. Process of bone formation by osteoblasts can be examined by bone marker such as Osteocalcin, as a parameter (alone or in combination with BMD) to determine metabolic bone disorders during bone formation and bone remodeling (bone turnover).
\end{abstract}

Aim: To analyze the correlation among BMD, BMI and Osteocalcin in Postmenopausal women, to investigate the possibility of using osteocalcin examination to predict the mandibular bone osteoporosis.

Method: Fifty four women above 51 years old who are at least 1 year postmenopausal, underwent BMD (using DEXA examinations), BMI, and Osteocalcin. The results of each examination were counted, and the correlations among each examinations were evaluated using Spearman's correlation test.

Result: Means of BMD, BMI, and Osteocalcin in postmenopausal women were 1.606, 25.189, and 30.566 respectively. BMD were significantly correlated with BMI (Spearman's rank correlation coefficient $r=0.414, p<0.05$ ). While, BMD were significantly correlated with Osteocalcin $(r=-0.343, p<0.05)$. Moreover, BMI were significantly correlated with Osteocalcin $(r=-0.274, p<0.05)$.

Conclusion: There were significant correlations among BMD, BMI, and Osteocalcin results in postmenopausal women. It is concluded that each examination of BMD, BMI, and Osteocalcin can be used to identify the risk of osteoporosis in postmenopausal women. Therefore simple examination of osteocalcin can be used to predict mandibular bone loss.

Keywords: BMD; BMI; Osteocalcin; Osteoporosis; Postmenopausal women

\section{Introduction}

Osteoporosis is a disease which requires more attention from the dentists, osteoporosis is related to the decrease of bone density, and it can also occurs in the jaw bone. The osteoporotic jaw bone will experience the decrease of jaw bone density, the increase alveolar jaw bone resorption, and also the increase risk of periodontal disease and tooth loss. It is crucial for dentists and especially prosthodontist to diagnose jaw bone density, especially in postmenopausal women before prosthodontic treatment. There are numerous failure in prosthodontic treatment due to osteoporosis. Osteoporosis will cause mandible resorption, which in turn cause the failure of osteointegration between the implant and the jaw bone [1].
Problem of osteoporosis in postmenopausal women is associated with the decrease of estrogen level. This condition will accelerate bone fragility [2]. World Health Organisation (WHO) defines osteoporosis as a disease that is characterized by low bone mass and microarchitectural destruction of bone tissue, leading to bone fragility and increased risk of fracture. Diagnosis of osteoporosis according to WHO is obtained from any of the three regions (total hip, femoral neck and lumbar spine). Study Group Meeting of WHO assesed fracture risks and applied it to screen postmenopausal osteoporosis, and recorded that more than 75 million people in the United States, Europe and Japan were suffering from osteoporosis on 2006. Osteoporosis caused more than 8.9 million fractures per year that occured in the United States and Europe [3]. While, research of Health Department showed that two out of five people in Indonesia have the risk of osteoporosis [4]. 
Diagnosis of osteoporosis is calculated with a quantitative assessment of bone density, which is called Bone Mineral Density (BMD) [5]. The best imaging modalities to assess bone density are the Dual Energy examination methods x-ray absorptiometry (DEXA) and Quantitative Computerized Tomography (CT). CT is more sensitive but with the added risk of more radiation exposure, several experts prefer DEXA examination due to the less radiation exposure. BMD in postmenopausal women is determined by peak bone mass and the amount of bone lost since menopause [6].

In addition to DEXA, osteoporosis examination can be done with Body Mass Index (BMI). BMI is a ratio of weight and height with units $\left(\mathrm{kg} / \mathrm{m}^{2}\right)$ [7]. Regarding to BMD and BMI, there are four important factors to assess the quality of bone, these are bone density; bone turnover (remodeling); bone size; and bone geometry (microarchitecture) [6].

Osteocalcin is known as bone Gla protein, a marker of bone formation, vitamin $\mathrm{K}$ and vitamin $\mathrm{D}$-dependent protein produced by osteoblasts and most widely studied of the non-collagen protein in bone [8]. Osteocalcin plays an important role in the process of mineralization and calcium ion homeostasis process. Osteocalcin is synthesized during the bone formation and it exhibits a compact, calcium dependent, alpha helical formation, in which the Gama Carboxyglutamic Acid (GLA) residues bind and promote absorbtion to hydroxyapatite in the bone matrix, thus leading to bone mineralization. Calcium and phosphorus deficient osteoporotic woman may have a decrease rate of bone mineralisation due to a reduction in hydroxypatite crystal formation [9].

The examination of osteocalcin is a good parameter for determining bone metabolism disorders during bone formation and bone turnover. This marker is often used as an early biomarker of bone-forming therapy and to assess the effectiveness of treatment outcome [6].

Relationship between BMD and BMI is still not clearly defined, some authors found out a positive relationship, while others showed that BMI is a risk factor for osteoporosis. There are some researches showed positive correlation between systemic osteoporosis and the decrease of mandibular bone density [10].

There is increasing evidence that a combination of a biochemical marker and BMD may be a better predictor of fracture than BMD alone, yet biochemical marker such as osteocalcin may also predict fracture risk independently of BMD. High bone turnover can distrupt the trabecular architecture by increasing the incidence of trabecular perforation and buckling, thus reducing bone strength, without necessarily appreciably affecting BMD [9].

In this study we analyzed the correlation among BMD (calculated from lumbar spine), BMI and Osteocalcin in postmenopausal women. While BMD is still the gold standart for osteoporosis diagnosis, the device is unfortunately limited in our country, osteocalcin examination in the other hand is easier, cheaper and more simple. Researcher wants to investigate the possibility of using osteocalcin examination to predict the mandibular bone osteoporosis.

\section{Materials and Methods}

\section{Study design}

This is a cross sectional observation study, conducted at Pramita and Prodia Laboratory. This study is using fifty four postmenopausal women who recieved prosthodontic treatment from January until March 2014 in prosthodontic clinic Airlangga University as subjects, and all of them were given informed consent to be examined. Characteristics of subjects were at least 1 year postmenopausal women, above 51 years old, no history of systemic diseases (Hyperparathyroidsm, Paget's Disease, Osteomalacia, Renal Osteodystrophy, Osteogenesis Imperfecta), no history of cancer or kidney diseases, no history of hormonal therapy and smoking.

\section{BMD measurement}

BMD is the main criteria used to diagnose and monitor osteoporosis. DEXA is the current gold standard examination of osteoporosis in male and female, which is used to examine the bone mass of total hip, femoral neck, lumbar spine, or whole body. The purpose of bone mass measurement are to determine diagnosis of osteoporosis, to predict the occurrence of fractures, to assess changes in bone density after treatment [11]. In this study, position of patients were in lumbar spine with center of laser beam in lumbal. Lumbar spine is measured in this research, due to the faster bone loss nature compared with the hip in post-menopausal women [12]. Measurement of bone density usually expressed in T-scores, where the standard deviations number of bone density varies from the average bone density in normal subjects with the same sex. WHO define osteoporosis as a condition in which bone mineral density is below -2.5 $\mathrm{SD}$, osteopenia in which bone mineral density between -1 to $-2.5 \mathrm{SD}$, while normal in which bone mineral density is above -1 SD [13].

\section{BMI measurement}

BMI is a person's weight in kilograms divided by the square of height in meters. Height was measured using a 0.1 microtoise $\mathrm{cm}$ precision. Body weight was measured using a digital weight scales Seca brands with $0.1 \mathrm{~kg}$ precision. BMI figure obtained by using the weight formula $\left(\mathrm{kg} / \mathrm{m}^{2}\right)$.

\section{Osteocalcin measurement}

The examination of osteocalcin is a good parameter to determine bone metabolism disorders during bone formation and bone turnover. Osteocalcin level were examined using enzyme-linked immunosorbent assay (ELISA). Normal values were: $10.1 \pm 9.4 \mathrm{ng} / \mathrm{ml}$ [6]. In vivo quantitative measurement of N-MID osteocalcin levels were performed in serum or plasma. Examination of the N-Mid Osteocalcin with postmenopausal scale $15-46 \mathrm{ng} / \mathrm{ml}$. Stability samples $2-80 \mathrm{C}$ (immediately after sampling), 200C (4 hours after sampling, 2 hours if the sample correction carried out in room temperature), $-800^{\circ} \mathrm{C}$ (more than 1 month). This examination is used as a therapeutic control antiresorp. Principles of inspection: The principle of this test is a sandwich ELISA.

In the first incubation, the sample will react with the monoclonal antibody spesific N-MID osteocalcin and biotin-labeled monoclonal antibodies specific N-MID osteocalcin labeled ruthenium complex to form a sandwich. Furthermore, the addition of streptavidin-coated 
Page 3 of 5

microparticles that cause complex bound to the solid phase via interaction of biotin and streptavidin. The reaction mixture is put into the measuring cell where the microparticles were captured with a magnet on the electrode surface, the compounds are not bound disposed pro cell. Voltage provision to the electrodes induces chemiluminescent emission. Results are determined via a calibration curve made by means of a two-point calibration curves and masks available on the reagent barcode.

\section{Ethical Clearance}

This study has recieved ethical clearence from the Comission on Ethics Health Research (KKPEK).

\section{Statistical Analysis}

Data analysis was performed using SPSS software (version 21.0; SPSS, Inc., Chicago, IL). Subject characteristics are presented as mean \pm SD unless otherwise stated. Agreement among BMD and BMI, and osteocalcin determined using Spearman's rank correlation coefficient. Significant correlation were found if $\mathrm{p}<0.05$.

\section{Results}

Characteristics of participants: There were fifty four postmenopausal women, with average age of 63, 78 years (range 51-83 years old), with $83.33 \%$ subjects were in the range of $51-65$ years old and $16.67 \%$ subjects were in range above 66 years old.

Difference mean of BMD, BMI, and osteocalcin are listed in Table 1. Mean of BMD, BMI, and osteocalcin were $1.606 \pm 1.213,25.189 \pm$ $4.076,30.566 \pm 9.144$. Based on BMD value, $27.8 \%$ of subjects were osteoporosis, $44.4 \%$ of subjects were osteopenia, and $27.8 \%$ were normal.

Agreement among BMD, BMI, and osteocalcin with nonpharametric method are listed in Table 2, with spearman rank correlation. Assessments of BMD and BMI were significantly related $(\mathrm{p}<0.05, \mathrm{r}=0.414$, positive relation). $\mathrm{BMD}$ and osteocalcin were significantly related ( $\mathrm{p}<0.05, \mathrm{r}=-0.343$, negative relation), as well as BMI and osteocalcin were also significantly related $(\mathrm{p}<0.05, \mathrm{r}=-0.274$, negative relation). BMD and BMI had a stronger relation compared with BMI and osteocalcin.

Correlation types are listed in Figure 1. Correlation between BMD and BMI showed linear positive, because dots in graph above were placed in positive axis. Higher BMD linear also has higher BMI. Correlation between BMD and osteocalcin were negative because dots in graph strive were placed in negative axis. Higher BMD has lower Osteocalcin, as well as correlation between BMI and osteocalcin.

\begin{tabular}{|l|l|l|}
\hline Category & Mean & Standard Deviation \\
\hline BMD & 1.606 & 1.213 \\
\hline BMI & 25.189 & 4.076 \\
\hline Osteocalcin & 30.566 & 9.144 \\
\hline
\end{tabular}

Table 1: Difference Means of BMD, BMI, and osteocalcin with standard deviation.

\begin{tabular}{|c|c|c|c|c|c|}
\hline \multicolumn{6}{|c|}{ Correlations } \\
\hline & & & BMD & BMI & $\begin{array}{l}\text { Osteocalci } \\
\mathrm{n}\end{array}$ \\
\hline \multirow{9}{*}{$\begin{array}{l}\text { Spearman' } \\
\text { s rho }\end{array}$} & \multirow{3}{*}{ BMD } & $\begin{array}{l}\text { Correlation } \\
\text { Coefficient }\end{array}$ & 1 & $.414^{* \star}$ & $-.343^{*}$ \\
\hline & & $\begin{array}{l}\text { Significance } \\
\text { tailed) }\end{array}$ & & 0.002 & 0.011 \\
\hline & & $\mathrm{N}$ & 54 & 54 & 54 \\
\hline & \multirow{3}{*}{ BMI } & $\begin{array}{l}\text { Correlation } \\
\text { Coefficient }\end{array}$ & $.414^{* \star}$ & 1 & $-.274^{*}$ \\
\hline & & $\begin{array}{l}\text { Significance } \\
\text { tailed })\end{array}$ & 0.002 & . & 0.045 \\
\hline & & $\mathrm{N}$ & 54 & 54 & 54 \\
\hline & \multirow{3}{*}{$\begin{array}{l}\text { Osteocalci } \\
\mathrm{n}\end{array}$} & $\begin{array}{l}\text { Correlation } \\
\text { Coefficient }\end{array}$ & $-.343^{*}$ & $-.274^{*}$ & 1 \\
\hline & & $\begin{array}{l}\text { Significance } \\
\text { tailed })\end{array}$ & 0.011 & 0.045 & . \\
\hline & & $\mathrm{N}$ & 54 & 54 & 54 \\
\hline \multicolumn{6}{|c|}{${ }^{* *}$. Corr. is significant at .01 level 2-tail... } \\
\hline
\end{tabular}

Table 2: Correlations among BMD, BMI, and osteocalcin with Spearman correlation statistical test.

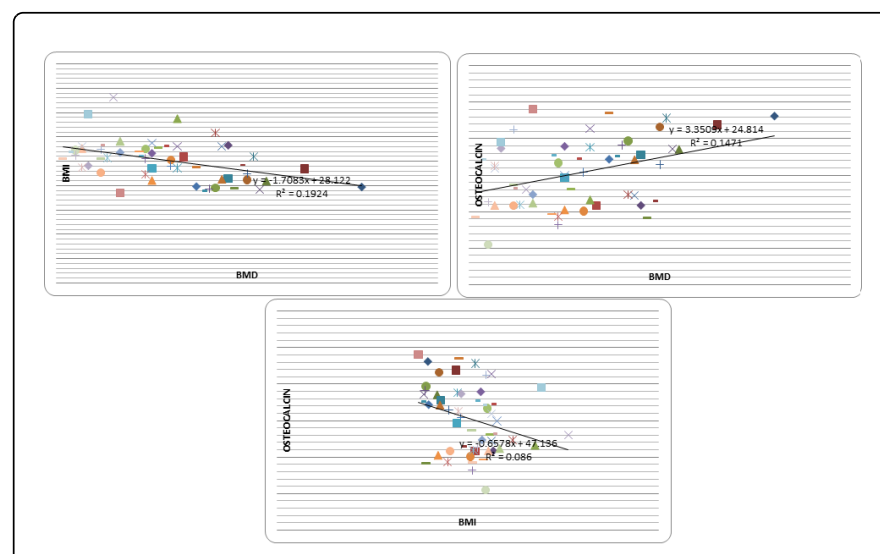

Figure 1: Scatterplot correlations from BMD and BMI, BMD and osteocalcin, BMI and osteocalcin.

\section{Discussion}

In this study, bone mineral density was evaluated using a DEXA of the spine. Density of the spine is most responsive to drugs intervention and monitoring for patient. DEXA is a technology to determine the relationship between bone density and fracture risk, and has been validated in a longitudinal cohort study. DEXA obtained some information about bone density in a given area in grams $/ \mathrm{cm} 2$, comparison between mean level of bone density compared to the mean level of bone density with the same ethnic adults called $\mathrm{T}$ score in percent (\%) [11]. 
This study showed that BMD and BMI had significant correlation (positive correlation) showed in Table 2. This result was consistent with those reported by Hsu et al. [14] and Ahmad et al. [15] which reported a significant positive relationship among weight, BMI and BMD. BMI is a good indicator and ofter used for measuring BMD [16], this is similiar with the research of Iqbal which suggested that BMI is a good indicator for referring patients to do DEXA scanning on Bone Mineral Density (BMD) [17]. The results of the bivariate analysis of Herkulina study showed positive and significant correlation between Body Mass Index (BMI) and Bone Mineral Density (BMD) [18].

The study of Kim et al. also stated that low body weight is more likely associated with osteoporosis [19]. All of height, weight and BMI positively correlated with the dependent variable BMD T-score. As well as research of Hubungan [20] showed that low BMI and decreased bone strength associated with reduced bone mass in all parts of the body. Study of Mendez et al. showed relationship of BMI and BMD was significantly positive at the lumbar spine, pelvis and femoral neck [21].

Correlation between BMD and osteocalcin had significant relationship (negative correlation) showed in Table 1, this is well according to the theory that as a specific marker of osteoblast function, level of osteocalcin have been shown to correlate with bone formation rates, osteoporotic post-menopausal women will have an increase of serum OC concentration. The same statement was made by Kalaiselvi et al. [22] which reported a negative correlation found between the osteocalcin level and the BMD in post-menopausal women (Pearson's correlation $\mathrm{p}<0.05$ and $\mathrm{r}=-0.595)$. That study in 60 post-menopausal women at Sree Balaji Medical College and Hospital and Bharat Scan Limited at Chennai, India, as well as study of Susanto [9] reported a significant inverse correlation between serum osteocalcin and femoral neck BMD $(\mathrm{p}<0.05$, and $\mathrm{r}=-0.29)$.

BMI and osteocalcin have significant correlation (negative correlation) showed in Table 2. The same statement is made by Kalaiselvi et al. [22] which reported that a significant correlation was found between osteocalcin level and BMD in post-menopausal women (Pearson's correlation $\mathrm{p}<0.05$, and $\mathrm{r}=0.339$ ).

Despite BMI usage as a measurement to predict whether a person is overweight or not, it has some drawbacks and may not be an accurate tool for assessing weight status and height. This study is similiar with that of body weight or BMI indicates the value inversely with markers of bone turnover, where people with low body weight has higher bone turnover, while overweight and obese have lower serum osteocalcin compared to normal weight. Effect of obesity on the risk of fracture depends on the definition, if defined by BMI or body weight, obesity may protect against bone mineral loss or vertebral fractures. However, if obesity is based on the percentage of body fat, obesity may be a risk factor for osteoporosis [9].

Osteoporosis is not only occured in lumbar, femur and radius bone, but also on jaw bone, researches have concluded that density of mandible bone related with density of other bones significantly [1]. Based on this research, there was a correlation among BMD, BMI and osteocalcin. Those examinations therefore can be used to predict osteoporosis of the mandible bone.

\section{Conclusion}

There were significant correlations among BMD, BMI, and Osteocalcin results in postmenopausal women. BMD and BMI had positive correlation, while BMD and osteocalcin had negative correlation, and BMI and osteocalcin had also negative correlation. It is concluded that examination of BMD, BMI, and Osteocalcin can be used to identify the risk of osteoporosis in postmenopausal women. Therefore simple examination of osteocalcin can be used to predict bone loss in mandibular bone.

\section{Acknowledgement}

To all of respondents whom involved in this study, and also Prodia laboratorium for examining osteocalcin.

\section{References}

1. Lindawati SK (2012) Dampak Osteoporosis Tulang Rahang Terhadap Perawatan Prosthodontik dan Kualitas Hidup Lansia. Pidato Pengukuhan Guru Besar FKG UI, pp. 3-15.

2. Abas BJ dan, Sri P (2007) Risiko Osteoporosis di Indonesi. Puslitbang Gizi dan Makanan Depkes RI Bogor 30: 1-11.

3. World Health Organization (2004) 'WHO Scientific Group on The Assessment of Osteoporosis at Primary Health Care Level.' Summary Meeting report Brussel, Belgium, pp.2

4. Ichramsjah AR, dan Bambang $S$ (2010) Penyakit Osteoporosis.

5. Compston J, Cooper A, Cooper C, Francis R, Kanis JA, et al. (2013) Guideline for the diagnosis and management of osteoporosis in postmenopausal women and men from the age of 50 years in the UK. Maturitas 62: 105-8.

6. Adi P (2007) Peran Pertanda Tulang Dalam Serum Pada Tata Laksana Osteoporois. Universa Medicina 26: 152-9.

7. Centers For Disease Control (2009) Body Mass Index: 'Considerations for Practitioners. Department of Health and Human Services, USA. pp. 1.

8. Lee AJ, Hodges S, Eatell R (2000) Measurement of Osteocalcin. Association of Clinical Biochemist 37: 432-446.

9. Susanto LTM (2011) Serum Osteocalcin and bone mineral density in postmenopausal women. Universa Medicina 30: 155-161.

10. Ishii K, Taguchi A, Nakamoto T, Ohtsuka M, Sutthiprapaporn P, et al. (2007) Diagnostic efficacy of alveolar bone loss of the mandible for identifying postmenopausal women with femoral osteoporosis. Dentomaxillofac Radiol 36: 28-33.

11. Kawiyana IKS (2009) Osteoporosis, Patogenesis Diagnosis dan Penanganan Terkini. J Penyakit Dalam 10: 158-162.

12. Bonnick SL, Shulman L (2006) 'Monitoring Osteoporosis Therapy: Bone Mineral Density, Bone Turnover Markers, or Both?'. The American Journal of Medicine 119: 255-315.

13. Margo U, Wulandari M, Zilfa KP (2010) Faktor-Faktor Yang Berhubungan Dengan Kepadatan Tulang Pada Wanita Postmenopause. Jurnal Unimus 6: 1-2;

14. Hsu YH, Venners SA, Terwedow HA, Feng Y, Niu T, et al. (2006) Relation of body composition, fat mass, and serum lipids to osteoporotic fractures and bone mineral density in Chinese men and women. Am J Clin Nutr 83: 146-54.

15. Ahmad EA, Abbas M, Amir R, Mohammad S (2012) 'the Relationship between Body Weight, Body Mass Index (BMI) and Bone Mineral Density (BMD) of the Lumbar Spine and Femoral neck in Professional Cyclist of Iran and Tour de France. Iranian Journal of Health and Physical Activity 4: 67-71.

16. Budi S, Sri P, Wasilah R, dan Retno P (2011) Hubungan Indeks Massa Tubuh Dengan Densitas Mineral Tulang Pada Perempuan Dewasa Muda. Pusat Penelitian dan Pengembangan Gizi dan Makanan, Badan Penelitian dan Pengembangan Kesehatan. Kemenkes RI 34: 93-103.

17. Iqbal SI, Morch LS, Rosenzweig M, Dela F (2005) The Outcome of Bone Mineral Density Measurements on Patients Referred From General Practise. Journal of Clinical Densitometry 8: 178-182. 
Citation: Hendrijantini N, Alie R, Setiawati R, Astuti ER, Wardhana MP (2016) The Correlation of Bone Mineral Density (BMD), Body Mass Index (BMI) and Osteocalcin in Postmenopausal Women. Biol Med (Aligarh) 8: 319. doi:10.4172/0974-8369.1000319

Page 5 of 5

18. Herkulina F (2012) Hubungan Indeks Massa Tubuh dan Komposis Tubuh dengan Densitas Massa Tulang Wanita Dewasa di Perwatusi Kota Pontianak. Electronic Tesis dan disertasi Universitas Gajah Mada.

19. Kim SJ, Yang WG, Cho E, Park E (2012) Relationship between Weight, Body Mass Index and Bone Mineral Density of Lumbar Spine in Women. J Bone Metab 19: 95-102.

20. Hubungan NA (2004) Tingkat Konsumsi Kalsium, Protein dan Status Gizi dengan Derajat Osteoporosis Pada lansia.
21. Mendez JP, Mejia DR, Pedraza J, Varquez RMC, Soriano R, et al. (2013) Bone Mineral Density in Postmenopausal Mexican-Mestizo Women with Normal Body Mass Index, Overweight, or Obesity. Menopause 20: 568-72.

22. Kalaselvi, Prabhu K, Ramesh M, Venkatesan V (2013) The Association of Serum Osteocalcin with the Bone Mineral Density in Post-Menopausal Women. J Clin Diagn Res 7: 814-816. 